\title{
MEĐUNARODNI I NACIONALNI OKVIRI ZAŠTITE ŽIVOTNE SREDINE
}

\author{
Ivan Joksić ${ }^{*}$ Goran Milojević** i Nada Đuričić*** \\ Pravni fakultet za privredu i pravosuđe u Novom Sadu
}

\begin{abstract}
ruga polovina 20. veka predstavlja period povećanog interesovanja za životnu sredinu. To je posebno slučaj u zemljama sa razvijenom industrijom koja proizvodi negativne efekte na životnu okolinu. U pitanju su tzv. prljave tehnologije koje profit stavljaju iznad svih ostalih dobara u društvu. Inventivnost proizvodnih procesa nisu pratila tehnička rešenja kojima bi se stalo na put omasovljenom zagađenju životne sredine. Ostvarivanje velikih profita uticalo je na odsustvo interesovanja za uspostavljanjem pravnoinstitucionalnih mehanizama proaktivnog i reaktivnog delovanja na sistematsko ugrožavanje zdravlja ljudi, putem zagađenja njihovog životnog prostora.

Možemo izdvojiti više domena životne sredine u čijim okvirima se ona štiti. Uvažavajući raznorodnost međunarodnih i nacionalnih pravnih instrumenata u oblasti životne sredine, u radu su izdvojeni oni kojima se ostvaruje najjači efekat. Zato je u fokusu izlaganja pravo na zdravu životnu sredinu kao ljudsko pravo i krivična dela kojima se inkriminiše zona njihovog narušavanja.
\end{abstract}

Ključne reči: životna sredina, međunarodni i nacionalni pravni instrumenti, ljudska prava, krivično pravo

\section{Uvodna razmatranja}

亏̌ivotna sredina predstavlja specifično pravno područje na kome se ukršta dejstvo normi različitih grana prava. Zato je od izuzetne važnosti napraviti jasnu demarkacionu liniju koja bi razdvojila međunarodne, regionalne i nacionalne pravne domene zaštite životne sredine. Iskorak u ovom pravcu bi svakako predstavljalo iznalaženje adekvatnih sredstava kojima bi se udarili temelji proaktivnog i reaktivnog nivoa zaštite prava ljudi na zdravu životnu sredinu.

$U$ literaturi se neretko izgradnja podesnih mehanizama zaštite životne sredine smatra idealom kome treba težiti ali koji nije lako dostići. Reč je o specifičnom pravnom području koji zahteva angažovanje različitih subjekata iz vladinog i nevladinog sektora. Njihov broj, nadležnosti, sadržaj mera i postupaka, način izbora i delokrug poslova je poslednjih decenija napredovao u toj meri da njihovo razmatranje zahteva multidiscplinaran pristup. Nisu retki autori koji područje životne sredine smatraju najsloženijim što rezultuje učešćem više subjekata međunarodnog, regionalnog i nacionalnog značaja.

\footnotetext{
* Vanredni profesor na Pravnom fakultetu za privredu i pravosuđe u Novom Sadu.

** Asistent na Pravnom fakultetu za privredu i pravosuđe u Novom Sadu.

*** Asistent na Pravnom fakultetu za privredu i pravosuđe u Novom Sadu.
} 
Angažovanje raznorodnih subjekata nije moguće bez propisivanja adekvatnih pravnih okvira. Na taj način se omogućava njihovo de iure i de facto delovanje čime se najefikasnije ostvaruje njihova uloga. Briga o životnoj sredini predstavlja ono čemu teže sva prosperitetna društva. Tome doprinosi opšta univerzalizacija važećih propisa kojima se na pravno harmoničan način unifikuju pravna sredstva zaštite životne sredine.

Pored toga, zdrava životna sredina je preduslov očuvanja ljudske egzistencije i normalnog razvoja društva što čini bitan faktor višeg odnosno zdravijeg života ljudi. Sistem zaštite životne sredine čine mere, uslovi i instrumenti za: održivo upravljanje, očuvanje prirodne ravnoteže, celovitosti, raznovrsnosti i kvaliteta prirodnih vrednosti i uslova za opstanak svih živih bića; sprečavanje, kontrolu, smanjivanje i sanaciju svih oblika zagađivanja životne sredine. Uspostavljanje i održavanje ovog sistema zahteva ostvarivanje više podjednako važnih aspekata zaštite: međunarodnog, regionalnog i nacionalnog. Posebnost sistema zaštite životne sredine ogleda se u činjenici da se tako postiže harmoničan odnos među različitim, horizontalno i vertikalno postavljenim, subjektima.

Navedeni razlozi opredeljujuće utiču da se pitanju zaštite životne sredine pristupi na krajnje objektivan način. Tako bi se ograničio uticaj profitabilnog dela društva koji sticanje dobiti smatra primarnim a zaštitu životne sredine sekundarnim ili usputnim pitanjem. Pri tom, ne treba zanemarivati činjenicu da zaštita životne sredine obuhvata mere za: smanjenje buke, kontrole vode, smanjenje štetnih ispusnih gasova iz industrijskih postrojenja i prometa, kontrolu kvaliteta prehrambenih proizvoda, zabrane proizvodnje jedinjenja koja razgrađuju ozonski omotač ili negativno kontaminiraju postojeće ekosisteme i dr. Sledstveno tome, zaštitu životne sredine je neophodno tretirati kao međunarodni problem koji ostvaruje svoje pozitivne/negativne efekte na regionalnom i nacionalnom nivou.

\section{Međunarodni okviri zaštite životne sredine}

\section{Međunarodni pravni instrumenti}

Ubrzani naučno-tehnološki razvoj u 20. veku je pored pozitivnih ostvario i negativne efekte. Oni se prepoznaju u narušavanju životne sredine kroz nekontrolisano otpuštanje neprerađenih otpadnih materijala (voda, gasova i drugih materija). To je iniciralo povećano interesovanja za rešavanje tzv. ekoloških pitanja na međunarodnom nivou. Na taj način bi se uzdigla ekološka svest bez čijeg prisustva nije moguća efikasna zaštita životne sredine. Iskorak u tom pravcu je predstavljalo pojačano interesovanje za rešavanje ekoloških problema koji su postali izraženi pedesetih godina 20-og veka. Rešavanje ekoloških problema je uzdignuto na međunarodni pijedestal jer se njihovim ne/rešavanjem u krajnjem ishodu dovodi u pitanje opstanak čoveka odnosno njegov život i zdravlje.

Prisustvo ekološke svesti u drugoj polovini 20. veka je opredmećivano kroz postupanje u individualnim slučajevima zagađenja životne sredine. Ovi slučajevi su svoj epilog ostvarivali kroz naknadu štete što je uostalom bilo centralni motiv oštećene strane u postupku. U tome je posebno prednjačilo pravosuđe SAD gde imamo primere sudskih sporova između pojedinaca i velikih kompanija.

Kontinuirane aktivnosti međunarodnih organizacija u oblasti životne sredine dovele su do uspostavljanja pravno-institucionalnih mehanizama. U pogledu pravnih mehaniza- 
ma neophodno je konstituisati sistem pravnih normi koje bi skupa bile deo društvenog sistema. ${ }^{1}$ Prvi koraci u tom smeru učinjeni su Deklaracijom Konferencije Ujedinjenih nacija o životnoj sredini usvojenoj u Stokholmu 1972. godine. ${ }^{2}$ Deklaracijom je definisano da je čovek istovremeno proizvod i tvorac svoje okoline, koja mu daje sredstva za život u fizičkom smislu i koja mu omogućava intelektualni, moralni, društveni i duhovni napredak. Kao osnovni cilj ekološkog razvoja navodi se smanjenje rizika u pogledu uslova života i poboljšanje kvaliteta života, uz poklanjanje posebne pažnje zaštiti životne sredine pri ostvarenju tih ciljeva. Uporedo sa Stokholmskom deklaracijom doneta je Odluka o osnivanju centralnog organa Ujedinjenih nacija koji bi se bavio problemom zaštite životne sredine i koordinacijom aktivnosti na ovom planu. Program Ujjedinjenih nacija za životnu sredinu (UNEP) je počeo sa radom naredne tj. 1973. godine. ${ }^{3}$

Dvadeset godina kasnije (1992.) održava se Konferencija UN o životnoj sredini i razvoju (UNCED) u Rio de Ženeiru. Izražena je globalna ekološka zabrinutost za pitanja globalnog zagrevanja i gubitka biološke raznovrsnosti. Period 1972-1992. godine obuhvata kulminirajući proces donošenja velikog broja međunarodnih pravnih instrumenata u oblasti životne sredine. Kao osnovni principi sadržani u ovoj Deklaraciji navedeni su: ${ }^{4}$

1. Održivi razvoj. Prilagođavanje strukture i dinamike ljudskih delatnosti strukturi i dinamici životne sredine vrši se tako da se zadovoljavanjem potreba sadašnjih generacija ne ugrožava pravo i mogućnost budućih generacija na povoljne uslove života.

2. Integralnost. Usklađen (održivi) privredni razvoj sa zaštitom životne sredine obezbeđuje se uspostavljanjem integralnog sistema zaštite životne sredine, planiranjem i upravljanjem prirodnim bogatstvima i sprovođenjem mera zaštite životne sredine.

3. Preventivnost. Zagađivanje životne sredine se sprečava na mestu nastajanja. Ako određene aktivnosti predstavljaju rizik ili opasnost po životnu sredinu, preduzimaju se posebne mere za njihovo sprečavanje ili ograničavanje.

4. Procena uticaja. Pri planiranju i sprovođenju aktivnosti koje bi mogle imati negativan uticaj na životnu sredinu, sprovodi se postupak procene uticaja na životnu sredinu.

5. Kvalitet. Zaštita životne sredine ostvaruje se propisivanjem normi kvaliteta životne sredine, proizvoda, procesa i usluga, kao i drugih mera i uslova zaštite životne sredine.

6. Ponovna upotreba i reciklaža. Materije koje se mogu ponovo upotrebiti, reciklirati ili biološki razgraditi imaju prednost pri korišćenju.

\footnotetext{
${ }^{1}$ A. Čavoški et al., Ekološko pravo, Službeni glasnik, Beograd, 2004, str. 72.

${ }^{2}$ Report of the United Nations Conference on the Human Environment, Stokholm, 5-16. jun 1972. (A/CONF.48/14/Rev.1), deo I, poglavlje I.

${ }^{3}$ Odlukom trećeg zasedanja Upravnog saveta UNEP-a iz 1975. godine, postojeći termin međunarodno pravo čovekove okoline zamenjen je terminom pravo životne sredine (Invironmental Law). „Na ovom zasedanju usvojena je i strategija daljeg razvoja prava zaštite životne sredine. Osnovni elementi strategije su: 1) sistematsko prikupljanje informacija u oblasti prava zaštite životne sredine; 2) razrada i razvoj osnovnih načela usvojenih na Stokholmskoj konferenciji; 3) podsticanje međunarodnog ugovornog regulisanja zaštite životne sredine i ulaganje napora da se i druge međunarodne organizacije više angažuju u domenu razvoja ekološkog prava; 4.) podsticanje univerzitetskih i drugih naučnih ustanova da u svoje programe unesu pravo životne sredine; 5) podsticanje uporednopravnog izučavanja nacionalnih zakonodavstava u domenu zaštite životne sredine; 6) pružanje tehničke pomoći za unapređenje ekološkog zakonodavstva u zemljama u razvoju.“ D. Popov, „Načela zaštite životne sredine u dokumentima ujedinjenih nacija, evropske unije i zakona o zaštiti životne sredine Republike Srbije“, Zbornik radova Pravnog fakulteta u Novom Sadu, br. 2/13, str. 132.

${ }^{4}$ Ibid., str. 133.
} 
7. Korisnik plaća. Korisnik prirodnog bogatstva plaća naknadu za njegovo korišćenje i obavezan je da rekultiviše degradirani prostor.

8. Zagađivač plaća. Zagađivač snosi troškove preduzimanja preventivnih i drugih mera zaštite životne sredine i odgovoran je za zagađivanje i štetu nanesenu životnoj sredini.

9. Javnost podataka. Podaci o stanju životne sredine su javni.

10. Obaveštavanja. Nadležni državni organi blagovremeno i objektivno obaveštavaju javnost o stanju životne sredine i o zagađenjima koja mogu predstavljati opasnost po život i zdravlje ljudi i životnu sredinu.

11. Obrazovanje i jačanje svesti. Naučne ustanove, ustanove u oblasti obrazovanja, informisanja, kulture i druge ustanove, kao i udruženja građana, u okviru svojih delatnosti, podstiču, usmeravaju i obezbeđuju unapređenje svesti o značaju zaštite životne sredine.

Međunarodni pravni okviri o kojima je bilo reči predstavljaju sistem normativnog uređenja oblasti životne sredine. Međutim, oni nisu dovoljno sredstvo zaštite od različitih oblika zagađenja životne sredine. Otuda je neophodno normirati principe i okvire institucionalne zaštite društva od široke lepeze mogućih oblika narušavanja životne sredine. To je postignuto donošenjem novog dokumenta kojim je učinjen značajan iskorak u pravcu demokratizacije politike životne sredine i razvoja institucija civilnog društva. Istovremeno je učinjen najznačajniji korak u povezivanju oblasti zaštite životne sredine i oblasti zaštite ljudskih prava. U pitanju je Konvencija o dostupnosti informacija, učešću javnosti u donošenju odluka i pristupu pravosuđu u pitanjima životne sredine, koja se naziva i Arhuska konvencija, usvojena 1998. godine. ${ }^{5}$

Demokratizacijom sredstava i načina zaštite životne sredine omogućava se da javnost što više i na što bolji način učestvuje u donošenju odluka. Zatim, neophodno je izgraditi pravila i procedure o učešću javnosti i stvoriti uslove da ta pravila i procedure što efikasnije funkcionišu u praksi. Odgovori na ova pitanja se nalaze upravo u ovoj Konvenciji. Njena svrha je da se ova pitanja postave na odgovarajuće osnove na području životne sredine kako bi bili obezbeđeni uslovi za primenu savremenih standarda u ovoj oblasti. U tom procesu se apostrofira važnost aparata javne uprave i svih koji vrše funkcije u ime javne uprave. ${ }^{6}$

\section{Evropski pravni instrumenti}

Na evropskom tlu se nastanak i razvoj ideje o potrebi pravnog uređenja životne sredine vezuje za sedamdesete godine 20. veka. Pariski samit (održan 1972. godine) šefova država ili vlada država članica tadašnjih Zajednica predstavlja početak primene komunitarne politike zaštite životne sredine. Komisija je sačinila akcione programe u cilju smanjenja zagađenja životne sredine (ljudi, životinja i biljnog sveta). Jedinstvena politika u oblasti životne sredine uspostavljena je Jedinstvenim evropskim aktom iz 1987. godine. Ovaj akt sadrži posebnu glavu pod nazivom „životna sredina“ na osnovu koje se obezbeđuje pravni okvir za buduću politiku Evropske zajednice u oblasti zaštite životne sredine.

\footnotetext{
${ }^{5}$ Convention on Access to Information, Public Participation in Decision-Making and Access to Justice in Environmental Matters (Aarhus Convention). Izvor:

file://C:/Users/Ivan/AppData/Local/Microsoft/Windows/Temporary\%20Internet\%20Files/Content.IE5/2GONRJ WQ/cep43e.pdf (dostupno 01.06.2019.).

${ }^{6}$ D. Todić, M. Durać, Demokratizacija politike životne sredine, Priručnik za primenu Arhuske konvencije za predstavnike javne vlasti, Regionalni centar za životnu sredinu za Centralnu i lstočnu Evropu, Beograd, 2003, str. 13.
} 
Ugovorom u Mastrihtu iz 1992. godine jača se politika Evropske zajednice u oblasti životne sredine. Komunitarni segment predstavlja prvi stub saradnje što podrazumeva zajedničko odlučivanje 15 država članica. Ovim Ugovorom se obezbeđuje dalje jačanje mesta i uloge politike Zajednice u oblasti životne sredine uključivanjem, među svoje osnovne ciljeve, i unapređivanja održivog i neinflatornog rasta uz poštovanje životne sredine (član 2.). Uporedo sa Mastrihtskim ugovorom nastupa izmenjena uloga Evropskog parlamenta i Saveta u donošenju odluka, odnosno jača uloga Evropskog parlamenta u razvoju politike životne sredine ustanovljavanjem procedure zajedničkog odlučivanja sa Savetom. ${ }^{7}$

Aktivnosti Evropske unije utemeljene su na preventivnim principima tako da šteta koja nastupi za životnu sredinu mora biti sprečavana na samom izvoru zagađivanja. Direktivama donetim u Evropskoj uniji ustanovljena je mogućnost krivičnog gonjenja zagađivača. Posebno telo koje prati i prikuplja informacije o pitanjima u vezi sa zaštitom životne sredine je Evropska agencija za životnu sredinu. Ona obezbeđuje državama članicama tehničke, naučne i ekonomske informacije koje se tiču zaštite životne sredine. Na taj način se proširuje područje u kojima se pruža institucionalna zaštita evropskih zemlja od zagađenja životne sredine. ${ }^{8}$

Strategija održivog razvoja Evropske unije počiva na ideji o neophodnosti učešća ekonomskih, socijalnih i ekoloških efekata svih sektorskih politika koje se moraju uzeti u obzir pri donošenju odluka. Posebna pažnja u dokumentima pridaje se principu predostrožnosti, principu zagađivač plaća, principu korisnik plaća i principu subsidijarnosti. Međutim, ovako formulisane principe treba posmatrati, pre svega, u kontekstu opštih ciljeva definisanih u Strategiji održivog razvoja, grupisanih u četiri grupe koji obuhvataju: 1) zaštitu životne sredine (obezbeđenje kapaciteta Zemlje radi podrške životu u svim njegovim formama, poštovanje granica prirodnih resursa na Planeti i obezbeđivanje visokog nivoa zaštite i unapređenja kvaliteta životne sredine; sprečavanje i smanjivanje zagađivanja životne sredine i unapređenje održive proizvodnje i potrošnje radi razdvajanja veze između ekonomskog rasta i degradacije životne sredine); 2) društvenu jednakost i koheziju (unapređivanje demokratskog, socijalnog, kohezivnog, zdravog, bezbednog društva i društva koje poštuje osnovna prava, kulturni diverzitet i jednake mogućnosti kao i borba protiv diskriminacije u svim oblicima); 3) ekonomski napredak (unapređenje prosperitetne, inovativne, znanjem bogate, konkurentne i eko-efikasne privrede koja obezbeđuje visok životni standard i punu i visokokvalitetnu zaposlenost u celoj EU); i 4) poštovanje međunarodne odgovornosti (podsticanje osnivanja i odbrana stabilnosti demokratskih institucija u celom svetu, zasnovanih na miru, bezbednosti i slobodi; aktivna promocija održivog razvoja širom sveta i obezbeđivanje uslova da unutrašnje i spoljne politike EU budu u saglasnosti sa globalnim održivim razvojem i njenim međunarodnim obavezama). ${ }^{9}$

\footnotetext{
${ }^{7}$ N. Dragojlović, T. Miščević (prir.), Životna sredina, Vodič kroz politike Evropske unije, Beograd, 2010, str. 21-22.

${ }^{8}$ „Neophodno je da se o životnoj sredini više ne misli samo iz ekoloških razloga, već zato što je to pravi način da se oživi ekonomija sa više održivosti i da se stvore nove šanse za zapošljavanje (neodložan i opsežan program većeg očuvanja energije i upotrebe obnovljivih izvora energije u Evropskoj uniji bi mogli do stvore jedan do dva miliona novih radnih mesta)... EU je strateški projektujući održivi rast i zapošljavanje strategijom Evropa 2020, u centar postavila inovacije i zelene poslove u podsticanju konkurencije, što uključuje, ali se ne ograničava na investicije u čistije tehnologije i infrastrukturu. Za ovakav razvojni koncept su potrebna nova zanimanja, savremena znanja i sposobnosti. U selektovanim zemljama EU rađene su analize zanimanja, preko različitih pojedinačnih studija slučajeva, i pokazana potreba da se postojeća zanimanja nadograde novim zelenim sposobnostima i znanjima". A. Mihajlov, Znanja potrebna za zelene poslove i zelenu ekonomiju - analiza iz perspektive integralne životne sredine, Univerzitet i održivi razvoj, Fakultet političkih nauka, Centar za ekološku politiku i održivi razvoj, Beograd, 2011, str. 89-90.

${ }^{9}$ N. Dragojlović, T. Miščević (prir.), op. cit., str. 42-43.
} 
Poznato je da pravo na zdravu životnu sredinu ima svoje uporište u oblasti ljudskih prava. Na području evropskih pravnih instrumenata izvore kojima se ovo pravo garantuje i štiti možemo podeliti u dve grupe: materijalne i formalne. Pod materijalnim izvorima prava podrazumevaju se osnovni razlozi koji utiču na stvaranje propisa i društvene snage koje su stvarale evropske propise. U formalne izvore prava Evropske unije ubrajamo oblike u kojima je sadržana volja osnivača, najpre Evropske zajednice, a posle Evropske unije, koji se u pravnoj teoriji dele na: primarne i sekundarne.

A) Primarni izvori u oblasti životne sredine sadrže osnivačke ugovore i opšta pravna načela. Pravo Evropske unije poznaje i kategoriju međunarodnih sporazuma koje zaključi Evropska zajednica sa trećim državama ili međunarodnim organizacijama a nalaze se ispod primarnog prava, a iznad sekundarnog prava. Ugovorom u Lisabonu iz 2007. godine (član 191-193.) propisani su pravci u kojima je potrebno dalje razvijati sistem pravne zaštite životne sredine na evropskom pravnom prostoru.

B) Sekundarne izvore prava u oblasti životne sredine čine propisi koje u posebnom postupku donose organi EU. Organi i institucije Unije donose različite vrste odluka (uredbe, direktive, odluke, preporuke i mišljenja, komunikacija) koje se odnose na različite pravne oblasti. Tako, uredbe obavezuju države članice i postaju deo unutrašnjeg zakonodavstva država članica. Direktivama se postavljaju ciljevi i rezultati koji se moraju ispuniti, s tim što države članice određuju mehanizme njihove primene. Odlukama se meritorno rešavaju konkretna pitanja i odnose se na sve ili pojedine države, pravna ili fizička lica. Mišljenja i preporuke predstavljaju neobavezujuće instrumente za države članice Evropske unije. Odnose se na određena pitanja i dileme koje se putem davanja mišljenja i preporuka rešavaju. ${ }^{11}$

U literaturi su prisutni različiti načini klasifikacije sekundarnih izvora prava u oblasti životne sredine. Najpotpunijom možemo smatrati sledeću: horizontalno zakonodavstvo, nuklearna bezbednost i radioaktivni otpad, zaštita i upravljanje vodama, monitoring atmosferskog zagađenja, sprečavanje zagađivanja bukom, hemikalije, industrijski rizici, biotehnologije, očuvanje divlje faune i flore, upravljanje otpadom i čiste tehnologije i civilna zaštita. ${ }^{12}$

Uspostavljanjem pravnih okvira EU je stvorila povoljan pravni ambijent u čijim okvirima se trebaju kretati države članice. U oblasti životne sredine neophodno je ponuditi rešenja koja bi obuhvatila tri nivoa delovanja: ekonomsko prelivanje, ekološko prelivanje i psihičko prelivanje. $^{13}$

Važan momenat u pogledu koncipiranja odgovornosti zbog nastale štete po životnu sredinu predstavlja Direktiva Evropske unije o odgovornosti u oblasti zaštite životne sredine iz 2004. godine. Direktivom se uspostavlja princip zagađivač plaća kao pravno sredstvo zaštite životne sredine. Ovaj princip podrazumeva primenu mera i postupaka koje imaju za cilj sprečavanje ili ublažavanje posledica nastale štete. ${ }^{14}$ Primena principa zaga-

\footnotetext{
${ }^{10}$ R. Vukadinović, Uvod u institucije i pravo Evropske unije, Udruženje za evropsko pravo, Kragujevac, 2012, str. 93.

${ }^{11}$ I. Džomić, Evropska unija - prošlost, sadašnjost i budućnost, Friedrich-Ebert-Stiftung, Sarajevo, 2010, str. 76-77.

${ }^{12}$ N. Dragojlović, T. Miščević (prir.), op. cit., str. 53-54.

${ }^{13}$ Prema: D. Damjanović, N. Mikašinović (prir.), Izazovi evropskih integracija u oblastima zaštite životne sredine i održivog razvoja lokalnih zajednica, PALGO Centar, Beograd, 2011, str. 27.

${ }^{14}$ D. Radojević, „Nova Direktiva Evropske unije o odgovornosti u oblasti zaštite životne sredine“, Međunarodna politika, br. 1-2/05, str. 188.
} 
đivač plaća pokazuje u praksi niz nedorečenosti. Shodno tome, izazove njegove primene možemo klasifikovati u tri vrste: ${ }^{15}$

1) Kako definisati zagađenje (ko su zagađivači)?

2) Koliko bi zagađivači trebalo da plate na osnovu emitovanog zagađenja?

3) Kome bi trebalo da se plati (državi ili onima koji snose posledice zagađenja)?

Ove dileme su posebno razmatrane prilikom integrisanja ovog principa u nacionalna zakonodavstva većine evropskih zemalja. Naša zemlja je ozakonila primenu principa zagađivač plaća čime je učinjen radikalan otklon u odnosu na raniji period.

\section{Nacionalni okviri zaštite životne sredine}

Pravo na zdravu životnu sredinu predstavlja osnovno ljudsko pravo. Pored međunarodnog, ovo pravo uživa zaštitu i u okviru nacionalnog zakonodavstva. Naša zemlja je pravno uredila oblast zaštite životne sredine koristeći dihotoman pristup. Pod tim se podrazumeva normiranje životne sredine kroz sistem opštih i posebnih propisa. Osnovni ili bazičan propis predstavlja Zakon o zaštiti životne sredine iz 2004 . godine. ${ }^{16}$ Poseban propis kojim su uspostavljeni krivičnopravni okviri zaštite životne sredine predstavlja Krivični zakonik iz 2005. godine. ${ }^{17}$ Koristeći se postojećim zakonskim rešenjima ukazaćemo na specifičnosti opšteg i posebnog sistema zaštite životne sredine u našoj zemlji.

\section{Opšti sistem zaštite životne sredine}

Sistem zaštite životne sredine u našoj zemlji je sadržan u važećim ustavnim i zakonskim normama. Ustav Srbije iz 2006. godine sadrži opšte odredbe u kojima se uređuje životna sredina. ${ }^{18} \mathrm{U}$ delu kojim se regulišu ljudska prava i slobode proklamovano je sledeće (član 74. Ustava):

- Svako ima pravo na zdravu životnu sredinu i na blagovremeno i potpuno obaveštavanje o njenom stanju.

- Svako, a posebno Republika Srbija i autonomna pokrajina, odgovoran je za zaštitu životne sredine.

- Svako je dužan da čuva i poboljšava životnu sredinu.

Propisana je obaveza Republike Srbije da, između ostalog, uređuje i obezbeđuje „održivi razvoj; sistem zaštite i unapređenja životne sredine; zaštitu i unapređivanje biljnog i životinjskog sveta; proizvodnju, promet i prevoz oružja, otrovnih, zapaljivih, eksplozivnih, radioaktivnih i drugih opasnih materija“ (član 97. Ustava). Takođe je ustanovljena obaveza autonomnih pokrajina (član 183. stav 2. t. 2. Ustava) i opština (član 190. stav 1. t. 6. Ustava) da se preko svojih organa staraju o zaštiti životne sredine. ${ }^{19}$

\footnotetext{
${ }^{15}$ I. Ljumović, „Princip „zagađivač plaća“: ekonomski ideal ili koncept zaštite životne sredine“, Zbornik radova: Pravni i ekonomski aspekti primene principa zagađivač plaća, Beograd, 2018, str. 19.

${ }^{16}$ Zakon o zaštiti životne sredine Republike Srbije („Službeni glasnik RS“, br. 135/04-95/18).

${ }^{17}$ Krivični zakonik Republike Srbije („Službeni glasnik RS“, br. 85/05-94/16).

${ }^{18}$ Ustav Republike Srbije („Službeni glasnik RS“, br. 98/06).

${ }^{19} \mathrm{U}$ uporednom pravu nadležnost za primenu javnih mera očuvanja životne sredine podeljena je između centralne vlasti i nižih jedinica vlasti, tako što se od svih ovih nosilaca javnih vlasti očekuje saradnja. Postupajući na ovaj način,
} 
Zakon o zaštiti životne sredine predstavlja integralni propis u kome su sadržani opšti okviri zaštite životne sredine u našoj zemlji. Osim toga, poslednjih decenija je usvojen veliki broj posebnih zakonskih propisa kojima se uređuju različiti aspekti životne sredine. Reč je o sledećim zakonima:

1) Zakon o proceni uticaja na životnu sredinu; ${ }^{20}$

2) Zakon o strateškoj proceni uticaja na životnu sredinu; ${ }^{21}$

3) Zakon o integrisanom sprečavanju i kontroli zagađivanja životne sredine. ${ }^{22}$

Navedeni zakoni predstavljaju katalog propisa koji čine celovit sistem ekološkog zakonodavstva u Srbiji. Pored toga, usvojen je čitav set ekoloških zakona koji bi trebali da doprinesu harmonizaciji naših propisa sa evropskim standardima u ovoj oblasti. Njima se uređuje zaštita od nejonizujućeg zračenja, zaštita vazduha, zaštita prirode, zaštita od buke u životnoj sredini, hemikalije, biocidne proizvode $\mathrm{dr}^{23}$

\section{Krivičnopravni sistem zaštite životne sredine}

Krivičnopravna dimenzija zaštite životne sredine se u našem zakonodavstvu ostvaruje preko inkriminacija prisutnih u Krivičnom zakoniku i u propisima sporednog zakonodavstva. Shodno tome je krivična dela protiv životne sredine moguće klasifikovati u tri kategorije: prava ekološka krivična dela, koja se nalaze u odredbama KZ Srbije (član 260-277.), kojima se štiti životna sredina u celini; neprava ekološka krivična dela, koja se nalaze u odredbama KZ Srbije ali u okviru krivičnih dela koja pripadaju drugim grupama; sporedna ekološka krivična dela, koja se nalaze van KZ Srbije u odredbama sporednog zakonodavstva. ${ }^{24}$

U literaturi postoje različite vrste klasifikacije krivičnih dela protiv životne sredine. Najprihvatljivija je unutrašnja sistematika krivičnih dela protiv životne sredine u četiri podgrupe:

- opšta grupa krivičnih dela protiv životne sredine (zagađenje životne sredine član 260. KZS, nepreduzimanje mera zaštite životne sredine član 261. KZS, protivpravna izgradnja i stavljanje u pogon objekata i postrojenja koji zagađuju životnu sredinu član 262 . KZS, oštećenje objekata i uređaja za zaštitu životne sredine član 263 . KZS, oštećenje životne sredine član 264. KZS, uništenje, oštećenje i iznošenje u inostranstvo zaštićenog prirodnog dobra član 265. KZS, povreda prava na informisanje o stanju životne sredine član 268. KZS);

- krivična dela u vezi sa opasnim materijama (unošenje opasnih materija u Srbiju i nedozvoljeno prerađivanje, odlaganje i skladištenje opasnih materija član 266 . KZS, nedozvoljena izgradnja nuklearnih postrojenja član 267. KZS);

\footnotetext{
najveći broj ustava utvrđuje da je reč o jednoj vrsti konkurentne nadležnosti. Kada je ustanovljavanje smernica za zaštitu životne sredine predstavljeno kao ekskluzivna nadležnost najviših (središnjih) državnih organa, ostavlja se prostor za utvrđivanje standarda dodatne zaštite na nižem stepenu, najčešće nivou lokalne samouprave. V. Mikić, „Zaštita životne sredine u uporednom ustavnom pregledu“, Zbornik radova: Ekologija i pravo, Beograd, 2012, str. 225-226.

${ }^{20}$ Zakon o proceni uticaja na životnu sredinu Republike Srbije („Službeni glasnik RS“, br. 135/04; 36/09).

${ }^{21}$ Zakon o strateškoj proceni uticaja na životnu sredinu Republike Srbije („Službeni glasnik RS“, br. 135/04; 88/10).

${ }^{22}$ Zakon o integrisanom sprečavanju i kontroli zagađivanja životne sredine Republike Srbije („Službeni glasnik RS“, br. 135/04; 25/15).

${ }^{23}$ S. Lilić, M. Drenovak Ivanović, Ekološko pravo, Pravni fakultet, Beograd, 2014, str. 117.

${ }^{24}$ Prema: D. Jovašević, „Ekološki kriminalitet u Srbiji - teorija, zakonodavstvo, praksa“, Zbornik radova: Ekologija i pravo, Niš, 2011, str. 234-235.
} 
- krivična dela protiv biljnog i životinjskog sveta (ubijanje i mučenje životinja član 269. KZS, prenošenje zaraznih bolesti kod životinja i biljaka član 270. KZS, nesavesno pružanje veterinarske pomoći član 271 . KZS, proizvodnja štetnih sredstava za lečenje životinja član 272. KZS, zagađivanje hrane i vode za ishranu, odnosno napajanje životinja član 273. KZS, pustošenje šuma član 274. KZS, šumska krađa član 275. KZS);

- krivična dela u vezi sa lovom i ribolovom (nezakonit lov član 276. KZS, nezakonit ribolov član 277. KZS). ${ }^{25}$

Koncepcija zaštite životne sredine je pravno neodvojiva od prava čoveka na zdravu životnu sredinu. Prvenstveno zato što je priznavanje ljudskih prava u postizanju najvišeg kvaliteta života za čovečanstvo u okviru postojećeg globalnog ekosistema. Ona se mogu sukobiti, onda gde zaštita prirode dođe u konflikt sa očuvanjem prava čoveka. ${ }^{26}$

Zaštitni objekt kod krivičnih dela protiv životne sredine, kako u nacionalnom krivičnom pravu, tako i u međunarodnom krivičnom pravu, treba tražiti u ljudskom pravu na zdravu i relativno očuvanu prirodnu sredinu. ${ }^{27}$

Krivičnopravna zaštita životne sredine u okvirima našeg Krivičnog zakonika (glava XXIV) nije celovito normirana. Oblast zaštite od buke nije obuhvaćena krivičnopravnom zaštitom usled čega se ona štiti u okviru prekršajnog prava. ${ }^{28}$

Opšte krivično delo, u okviru grupe krivičnih dela protiv životne sredine, jeste zagađenje životne sredine (član 260. KZS). Osnovni oblik krivičnog dela postoji kada učinilac kršeći propise o zaštiti, očuvanju i unapređenju životne sredine zagadi vazduh, vodu ili zemljište u većoj meri ili na širem prostoru. Radnja krivičnog dela je posledično određena i sastoji se u širokoj lepezi načina izvršenja. Potrebno je da se preduzetim radnjama ostvari posledica krivičnog dela tako što se kršenjem propisa o zaštiti, očuvanju i unapređenju životne sredine zagadi vazduh, voda ili zemljište u većoj meri ili na širem prostoru. Kršenje propisa iz sporednog zakonodavstva, kojima se reguliše oblast životne sredine, kroz zaštitu, čuvanje i unapređenje, govori nam o akcesornoj ulozi krivičnog prava u odnosu na relevantne odredbe upravnog zakonodavstva. Treći i četvrti oblik ovog krivičnog dela postoje kada je došlo do uništenja ili oštećenja životinjskog ili biljnog sveta velikih razmera ili do zagađenja životne sredine u toj meri da su za njegovo otklanjanje potrebni duže vreme ili veliki troškovi. ${ }^{29}$

Zastupljenost ekoloških krivičnih dela u praksi pokazuje dominaciju krivičnog dela zagađenje životne sredine. Tome je doprinelo konstituisanje krivične odgovornosti pravnih lica 2008. godine. ${ }^{30} \mathrm{U}$ praksi imamo dominaciju uslovne osude kao najčešće izricane krivične sankcije pravnim licima. Ovaj trend je prisutan i u situacijama kada su pravna lica akteri krivičnih dela protiv životne sredine.

\footnotetext{
${ }^{25}$ B. Čejović, Krivično pravo - opšti i posebni deo, Dosije, Beograd, 2006, str. 582-583.

${ }^{26}$ I. Krstić, „Pravo na zdravu životnu sredinu u korpusu ljudskih prava“, Pravni život, br. 9/05, str. 621.

${ }^{27}$ Z. Stojanović, „Krivično-pravna zaštita životne sredine“, Pravni život, br. 9/95, str. 295.

${ }^{28}$ Z. Stojanović, Komentar Krivičnog zakonika, Službeni glasnik, Beograd, 2009, str. 605.

${ }^{29}$ Ostala krivična dela protiv životne sredine, sadrže različite aspekte zaštite koji uključuju aktivno i pasivno postupanje učinilaca (pravnih i fizičkih lica). I. Joksić, „Krivičnopravna zaštita životne sredine u zakonodavstvu i praksi“, Zbornik radova: Ekologija i pravo, Beograd, 2012, str. 24-25.

${ }^{30}$ Zakon o odgovornosti pravnih lica za krivična dela Republike Srbije („Sl. glasnik RS“, br. 97/08).
} 


\section{Zaključak}

Životna sredina predstavlja područje na kome se prelamaju norme međunarodnog i nacionalnog prava. Inicijativa za pravno uređenje ove oblasti počinje u drugoj polovini prošlog veka. Posle drugog svetskog rata je usvojen veliki broj međunarodnih i regionalnih pravnih instrumenata. Otuda pravno uređenje životne sredine možemo posmatrati kroz prizmu opštih i posebnih pravnih instrumenata. Prvima se regulišu različite vrste ljudskih prava čime se potvrđuje njihov urođeni karakter i odsustvo mogućnosti nedozvoljenih ograničenja. Drugima se ciljano reguliše oblast životne sredine čime se na celovit način pruža zaštita životne sredine sa pozicija različitih grana prava (međunarodnog, građanskog, krivičnog, prekršajnog i dr.). Na ovaj način je zaokružen sistem pravne zaštite životne sredine, čime se stvaraju povoljni okviri za institucionalno delovanje u domenu proaktivne i reaktivne zaštite životne sredine.

Nacionalni domen zaštite životne sredine podrazumeva primenu međunarodnih i evropskih standarda koji su implementirani u unutrašnji pravni poredak. Reč je o primeni dvostrukih pravnih standarda od kojih prvi pripadaju domenu nadnacionalnog a drugi nacionalnog prava.

Nadnacionalni sistem zaštite životne sredine obuhvata čitavu lepezu međunarodnih, evropskih i regionalnih pravnih instrumenata. U njihovom središtu je životna sredina koja se tretira kao ljudsko pravo treće generacije. Na osnovu toga je formulisano više principa koji služe potpunijoj pravno-institucionalnoj zaštiti životne sredine. U tom smislu rukovodni princip, koga se moraju pridržavati evropske zemlje, jeste zagađivač plaća. On je ugrađen u unutrašnje propise, kao način nadoknade štete, koju je prouzrokovač zagađenja učinio svojim štetnim delovanjem.

Nacionalni sistem zaštite životne sredine ima svoje pravno utemeljenje u propisima koji pripadaju domenu opšteg i posebnog zakonodavstva. Sistem opštih propisa obuhvata ustav i zakonske propise kojima se reguliše oblast životne sredine. Pored toga, životna sredina uživa krivičnopravnu zaštitu preko inkriminacija koje pripadaju grupi krivičnih dela protiv životne sredine.

\section{Literatura}

[1] Вукадиновић Р.: Увод у институције и право Европске уније, Удружење за европско право, Крагујевац, 2012.

[2] Драгојловић Н., Мишчевић Т. (прир.): Животна средина, Водич кроз политике Европске уније, Београд, 2010.

[3] Дамјановић Д., Микашиновић Н. (прир.): Изазови европских интеграција у областима заштите животне средине и одрживог развоја локалних заједница, ПАЛГО Центар, Београд, 2011.

[4] Јовашевић Д.: „Еколошки криминалитет у Србији - теорија, законодавство, пракса“, Зборник радова: Екологија и право, Ниш, 2011.

[5] Јоксић И.: „Кривичноправна заштита животне средине у законодавству и пракси“, Зборник радова: Екологија и право, Београд, 2012.

[6] Крстић И.: „Право на здраву животну средину у корпусу људских права“, Правни живот, бр. 9/05.

[7] Лилић С., Дреновак Ивановић М.: Еколошко право, Правни факултет, Београд, 2014. 
[8] Љумовић И.: „Принцип „загађивач плаћа“: економски идеал или концепт заштите животне средине“, Зборник радова: Правни и економски аспекти примене принципа загађивач плаћа, Београд, 2018.

[9] Микић В.: „Заштита животне средине у упоредном уставном прегледу“, Зборник радова: Екологија и право, Београд, 2012.

[10] Михајлов А.: Знања потребна за зелене послове и зелену економију - анализа из перспективе интегралне животне средине, Универзитет и одрживи развој, Факултет политичких наука, Центар за еколошку политику и одрживи развој, Београд, 2011.

[11] Попов Д.: „Начела заштите животне средине у документима уједињених нација, европске уније и закона о заштити животне средине Републике Србије“, Зборник радова Правног фракултета у Новом Саду, бр. 2/13.

[12] Радојевић Д.: „Нова Директива Европске уније о одговорности у области заштите животне средине“, Међународна политика, бр. 1-2/05.

[13] Report of the United Nations Conference on the Human Environment, Stokholm, 5-16. jun 1972. (A/CONF.48/14/Rev.1).

[14] Стојановић 3.: „Кривично-правна заштита животне средине“, Правни живот, бр. 9/95.

[15] Стојановић 3.: Коментар Кривичног законика, Службени гласник, Београд, 2009.

[16] Тодић Д., Дураћ М.: Демократизација политике животне средине, Приручник за примену Архуске конвенције за представнике јавне власти, Регионални центар за животну средину за Централну и Источну Европу, Београд, 2003.

[17] Чавошки A. et al.: Еколошко право, Службени гласник, Београд, 2004.

[18] Чејовић Б.: Кривично право - општи и посебни део, Досије, Београд, 2006.

[19] Џомић И.: Европска унија - прошлост, садашњост и будућност, Friedrich-Ebert-Stiftung, Сарајево, 2010.

\section{Propisi}

[1] Convention on Access to Information, Public Participation in Decision-Making and Access to Justice in Environmental Matters (Aarhus Convention).

[2] Устав Републике Србије („Службени гласник РС“, бр. 98/06).

[3] Закон о заштити животне средине Републике Србије („Службени гласник РС“, бр. 135/04-95/18).

[4] Кривични законик Републике Србије („Службени гласник PC“, бр. 85/05-94/16).

[5] Закон о процени утицаја на животну средину Републике Србије („Службени гласник PC“, бр. 135/04; 36/09).

[6] Закон о стратешкој процени утицаја на животну средину Републике Србије („Службени гласник PC“, бр. 135/04; 88/10).

[7] Закон о интегрисаном спречавању и контроли загађивања животне средине Републике Србије („Службени гласник РС“, бр. 135/04; 25/15).

[8] Закон о одговорности правних лица за кривична дела Републике Србије („Сл. гласник РС“, бр. 97/08). 